\title{
Low Expression of Single-stranded DNA Binding Protein 2 (SSBP2) Predicts Unfavourable Postoperative Outcomes in Patients With Clear Cell Renal Cell Carcinoma
}

\author{
HYUNSUNG KIM, YESEUL KIM, SEONGSIK BANG, SEONGEON PARK, SEUNGYUN JEE, \\ JONGMIN SIM, SU-JIN SHIN, SEUNG SAM PAIK and KISEOK JANG \\ Department of Pathology, College of Medicine, Hanyang University, Seoul, Republic of Korea
}

\begin{abstract}
Background: Single-stranded DNA binding protein 2 (SSBP2) is a subunit of a single-stranded DNA binding complex, which is involved in the maintenance of hematopoietic stem cells and stress responses. Numerous studies have suggested that SSBP2 functions as a tumor suppressor and is silenced through a pathway mediated by promoter hypermethylation. However, the role of SSBP2 in human renal cell carcinoma has not been reported, to date. Herein, we investigated the clinicopathological significance of SSBP2 expression in clear cell renal cell carcinoma (ccRCC). Materials and Methods: We constructed tissue microarrays consisting of 173 ccRCC tissues, and SSBP2 expression was evaluated semi-quantitatively based on the staining intensity and the proportion of stained cells. Regarding statistical analysis, the tissues were divided into two groups according to SSBP2 expression, and correlation of SSBP2 expression with various clinicopathological characteristics and patient outcomes was evaluated. Results. Low SSBP2 expression was observed in 114 of 175 (65.9\%) of ccRCC cases, and low SSBP2 expression was significantly correlated with larger tumor size ( $p=0.005$, Chi-square test), higher WHO/ISUP histological grade $(p<0.001$, Chi-square test), tumor necrosis ( $p=0.008$, Chi-square test), sarcomatoid change ( $p=0.021$, Chi-square test), and higher $p T$ AJCC stage ( $p=0.002$, Chi-square test). Kaplan-Meier survival curves revealed that patients with low SSBP2 expression had worse recurrence-free survival ( $p=0.041$, log-rank test).
\end{abstract}

This article is freely accessible online.

Correspondence to: Kiseok Jang, MD, Ph.D., Department of Pathology, College of Medicine, Hanyang University, 222 Wangsimniro, Seongdong-gu, Seoul 04763, Republic of Korea. Tel: +82 222908960, Fax: +82 222967502, e-mail: medartisan@hanyang.ac.kr

Key Words: Clear cell renal cell carcinoma, single-stranded DNA binding protein 2 , immunohistochemistry, cancer prognosis.
Conclusion: ccRCC with low SSBP2 expression was associated with adverse clinicopathological characteristics and poor patient outcomes.

Renal cell carcinoma (RCC) is the most common malignancy in the kidney and is the ninth most common cancer in both men and women in Korea (1). Clear cell renal cell carcinoma (ccRCC) is a histological subtype of RCC that accounts for about $80 \%$ of all RCC cases (2). Although nephrectomy can cure most localized ccRCCs, distant or local recurrence occurs in $20-30 \%$ of patients within 5 years after curative surgery $(3,4)$. Recent proteomic analyses revealed numerous dysregulated proteins and cancer-related signalling pathways in RCC, which are potential diagnostic and prognostic biomarkers and molecular targets for treatment $(5,6)$. However, due to the molecular phenotype heterogeneity of $\mathrm{RCC}$, there is no well-established molecular biomarker for prognosis $(7,8)$. Therefore, prognostic biomarkers for ccRCC are greatly needed.

Single-stranded DNA binding protein 2 (SSBP2) was isolated as a tumor suppressor of myeloid leukemia and is located in a critical region of loss in chromosome 5q14.1 (9). SSBP2 is a subunit of a ssDNA-binding complex that is involved in the maintenance of hematopoietic stem cells and stress responses (10). SSBPs interact with the transcriptional adaptor protein Lim domain-binding protein 1 (LDB1) through a highly conserved amino terminal motif (11); LDB1 binds to the LIM domains of LIM only proteins (LMO) and LIM homeodomain proteins (LHX) through a carboxyterminal LIM interacting domain (12). Although precise levels of LMO, LHX, and LIM-binding proteins are known to be critical for many developmental programs, accumulating evidence suggests that these complexes are also key molecules in various human cancers (13). The role of SSBP2 in human malignancies is an area of active investigation, and many studies have suggested that SSBP2 functions as a tumour suppressor and is silenced through a pathway mediated by promoter hypermethylation (14-18). However, among 
glioblastoma patients, a SSBP2 variant was associated with poor survival (19), and the role of SSBP2 in human RCC has not yet been reported (20).

To determine the clinical role of SSBP2 in human ccRCC, we investigated the expression of SSBP2 in ccRCC tissues by immunohistochemistry. The association of SSBP2 expression with various clinicopathological characteristics was assessed as well as whether SSBP2 is a prognostic factor for patient survival.

\section{Materials and Methods}

Patients and tumour samples. We enrolled a consecutive series of 252 patients with RCC in this study. All cases were diagnosed and underwent surgery at Hanyang University Hospital (Seoul, Korea) between 2006 and 2015. Patients who were diagnosed with nonccRCC or had incomplete clinical follow-up data or unavailable paraffin blocks were excluded, leaving 173 patients. The median follow-up period was 80 months (range, 6-141 months). Patients were divided into Histologic grades 1 to 4 according to the World Health Organization/International Society of Urological Pathology (WHO/ISUP) grading system. Pathologic stage was determined according to the $8^{\text {th }}$ edition of the American Joint Committee on Cancer (AJCC) staging system. We reviewed all hematoxylin and eosin (H\&E)-stained slides, pathology reports, and other medical records to confirm the diagnoses. The clinicopathologic parameters assessed were tumour size, histologic grade (WHO/ISUP grading system), lymphovascular invasion (renal vein tumour thrombus was included), sinus fat invasion, perirenal soft tissue involvement, tumour necrosis, sarcomatoid change, and pT AJCC stage. This study was approved by the Institutional Review Board of Hanyang University Hospital (HYUH 2018-05-005), and the requirement for informed consent was waived.

Tissue microarray construction. We used a manual tissue microarrayer (Unitma, Seoul, Korea) to construct the tissue microarray (TMA) from archival formalin-fixed, paraffin-embedded tissue blocks. Non-necrotic tissues that were most representative of the centre of the carcinoma, spanning $0.5 \mathrm{~cm}$ or larger, were selected from the H\&E-stained sections under light microscopy. Tissue cylinders $(2-\mathrm{mm}$ in diameter) were punched from a previously marked lesion of each donor block and transferred to the recipient block (Unitma). Each TMA was comprised of $5 \times 10$ samples.

Immunohistochemical staining. The immunohistochemical staining for SSBP2 was performed with 4- $\mu \mathrm{m}$-thick sections from the TMA blocks. The sections were deparaffinized in xylene and then rehydrated through graded ethanol. For antigen retrieval, the sections were heated in sodium citrate buffer $(\mathrm{pH}$ 6.0) in an autoclave at $100^{\circ} \mathrm{C}$ for $20 \mathrm{~min}$. Endogenous peroxidase activity was blocked with peroxidase blocking solution (S2023; Dako, Glostrup, Denmark). The TMA slides were incubated with primary antibodies at $4^{\circ} \mathrm{C}$ overnight and then incubated with a labelled polymer (EnVision/HRP, K5007; Dako) for $30 \mathrm{~min}$ at room temperature. The primary antibody was a rabbit monoclonal anti-SSBP2 antibody (EPR11520, 1:100 dilution). The antigen detected by the monoclonal SSBP2 antibody (ab177944, Abcam, Cambridge, MA, USA) was reported to be a synthetic peptide 300 aa from the C-terminus
Table I. Baseline characteristics of studied cases ( $n=173)$

\begin{tabular}{lc}
\hline Factors & Value $(\%)$ \\
\hline Number of patients & $173(100 \%)$ \\
Median age at surgery (years) & $58( \pm 12.18)$ \\
Mean tumor size & $3.63( \pm 2.31)$ \\
Gender & \\
Male & $123(71.1 \%)$ \\
Female & $50(28.9 \%)$ \\
WHO/ISUP grade & \\
Grade 1 & $22(12.7 \%)$ \\
Grade 2 & $95(54.9 \%)$ \\
Grade 3 & $46(26.6 \%)$ \\
Grade 4 & $10(5.8 \%)$ \\
pT stages & \\
pT1a & $108(62.4 \%)$ \\
pT1b & $25(14.5 \%)$ \\
pT2a & $6(3.5 \%)$ \\
pT2b & $0(0.0 \%)$ \\
pT3 & $34(19.6 \%)$ \\
\hline
\end{tabular}

(Cysteine residue). Finally, 3, 3'-diaminobenzidine tetrahydrochloride was used as a chromogen for detection, and the tissues were counterstained with Mayer's hematoxylin.

Interpretation of immunohistochemical staining. Nuclear staining of the tumour cells was assessed using the $\mathrm{H}$-score method (staining intensity $\times$ percentage of positive cells for each intensity score). Staining intensity was graded as follows: none $=0$, weak $=1$, moderate $=2$, and strong $=3$. Representative micrographs are shown in Figure 1. ROC curve analysis was performed to determine the cut-off score for low SSBP2 expression for survival endpoints (21). Expression below the diagnostic cut-off, i.e. an $\mathrm{H}$-score $<100$, was defined as low SSBP2 expression.

Statistical analysis. The statistical analysis was performed using SPSS software, version 21 (IBM, Armonk, NY, USA). The chisquare test was used to evaluate the correlations between SSBP2 expression and the clinicopathologic parameters of tumour size, WHO/ISUP grade, lymphovascular invasion, sinus fat invasion, perirenal soft tissue involvement, tumour necrosis, sarcomatoid change, and pT AJCC stage. Recurrence-free survival and cancerspecific survival were determined using Kaplan-Meier survival curves, and the log-rank test was used to compare the differences. A $p$-value less than 0.05 was considered statistically significant.

\section{Results}

Patient characteristics. Baseline characteristics of patients are summarized in Table I. The median patient age was 58 years (range=28-83 years), and the male to female ratio was 2.46:1. Pathologic evaluation revealed that the mean tumour size was $3.63 \mathrm{~cm}( \pm 2.31 \mathrm{~cm})$. According to the WHO/ISUP grading system, 22 cases $(12.7 \%)$ were grade $1,95(54.9 \%)$ were grade $2,46(26.6 \%)$ were grade 3 , and $10(5.8 \%)$ were grade 4. According to the $8^{\text {th }}$ AJCC staging system, 133 cases 

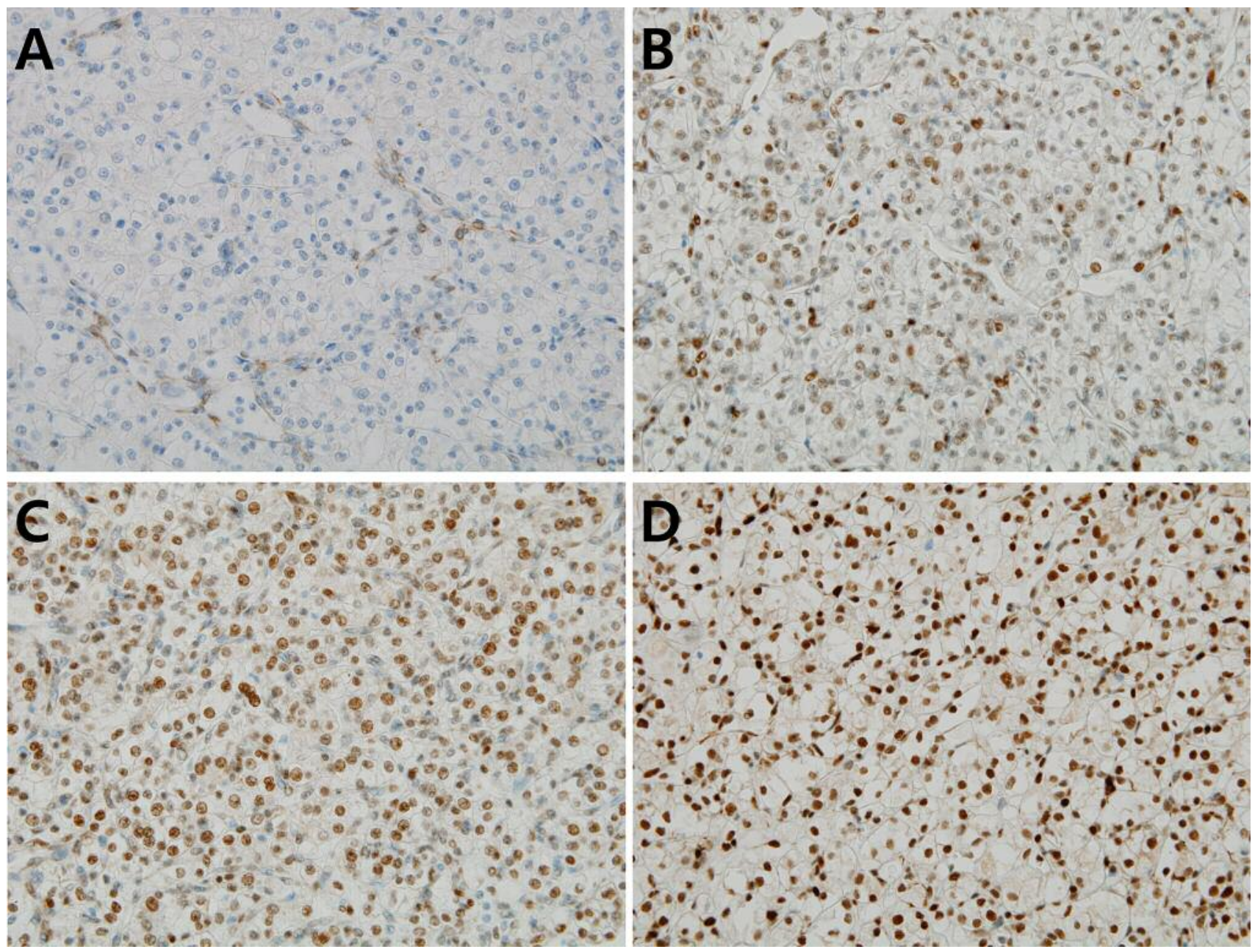

Figure 1. Representative micrographs of immunohistochemical staining for SSBP2 in clear cell renal cell carcinoma tissues. The intensity of nuclear staining was scored as negative (A), weakly positive (B), moderately positive $(C)$, and strongly positive (D) (A-D: Original magnification, $\times 200)$.

(76.9\%) were pT1, 6 (3.5\%) were pT2, 34 (19.6\%) were pT3, and none was pT4.

Correlations between SSBP2 expression and clinicopathological characteristics. High SSBP2 expression was observed in $34.1 \%(59 / 173)$ of the ccRCC samples, and low SSBP2 expression was observed in $65.9 \%(114 / 173)$ of the ccRCC samples. Low SSBP2 expression was significantly correlated with larger tumour size ( $p=0.005$, Chi-square test), higher WHO/ISUP histologic grade $(p<0.001$, Chi-square test), tumour necrosis $(p=0.008$, Chi-square test), sarcomatoid change ( $p=0.021$, Chi-square test), and higher pT AJCC stage ( $p=0.002$, Chi-square test) (Table II).

Correlations between SSBP2 expression and patient outcomes. Kaplan-Meier survival curves showed that patients with low SSBP2 expression had worse recurrence-free survival
( $p=0.041$, log-rank test) (Figure 2A). There also was a tendency toward worse cancer-specific survival for patients with negative SSBP2 expression, but it was not statistically significant ( $p=0.061$, log-rank test) (Figure 2B). In multivariate survival analyses, a loss of SSBP2 expression was not an independent prognostic factor for recurrence-free or cancerspecific survival (data not shown).

\section{Discussion}

SSBP2 is a well-known tumour suppressor in acute myelogenous leukaemia. However, the role of SSBP2 as a tumour promoter or suppressor in various human malignancies is controversial (14). Most studies in many human cancers, such as prostate, oesophageal, ovarian, and gallbladder cancers, have reported SSBP2 as a tumour suppressor that is silenced by promoter hypermethylation. Liu et al. detected SSBP2 
Table II. Correlation between SSBP2 expression and clinicopathologic factors in clear cell renal cell carcinoma.

\begin{tabular}{|c|c|c|c|c|}
\hline \multirow[b]{2}{*}{ Clinicopathologic Factors } & \multirow[b]{2}{*}{$\mathrm{n}$} & \multicolumn{2}{|c|}{ SSBP2 expression } & \multirow[b]{2}{*}{$p$-Value } \\
\hline & & $\begin{array}{c}\text { Low }(\%) \\
(\mathrm{n}=114)\end{array}$ & $\begin{array}{c}\text { High }(\%) \\
(\mathrm{n}=59)\end{array}$ & \\
\hline Tumor size & & & & 0.005 \\
\hline$\leq 4 \mathrm{~cm}$ & 121 & $72(59.5 \%)$ & $49(40.5 \%)$ & \\
\hline$>4 \mathrm{~cm}$ & 52 & $42(80.8 \%)$ & $10(19.2 \%)$ & \\
\hline WHO/ISUP grade & & & & $<0.001$ \\
\hline Grade $1 \& 2$ & 117 & $63(53.8 \%)$ & $54(46.2 \%)$ & \\
\hline Grade $3 \& 4$ & 56 & $51(91.1 \%)$ & $5(8.9 \%)$ & \\
\hline Lymphovascular invasion* & & & & 0.433 \\
\hline Absent & 171 & $112(65.5 \%)$ & $59(34.5 \%)$ & \\
\hline Present & 2 & $2(100.0 \%)$ & $0(0.0 \%)$ & \\
\hline Sinus fat invasion & & & & 0.567 \\
\hline Absent & 171 & $113(66.1 \%)$ & $58(33.9 \%)$ & \\
\hline Present & 2 & $1(50.0 \%)$ & $1(50.0 \%)$ & \\
\hline Perirenal soft tissue involve & & & & 0.433 \\
\hline Absent & 171 & $112(65.5 \%)$ & $59(34.5 \%)$ & \\
\hline Present & 2 & $1(50.0 \%)$ & $1(50.0 \%)$ & \\
\hline Tumor necrosis & & & & 0.008 \\
\hline Absent & 148 & $92(62.2 \%)$ & $56(37.8 \%)$ & \\
\hline Present & 25 & $22(88.0 \%)$ & $3(12.0 \%)$ & \\
\hline Sarcomatoid change & & & & 0.021 \\
\hline Absent & 164 & $105(64.0 \%)$ & $59(36.0 \%)$ & \\
\hline Present & 9 & $9(100.0 \%)$ & $0(0.0 \%)$ & \\
\hline pT AJCC stage & & & & 0.002 \\
\hline pT1 & 133 & $80(60.2 \%)$ & $53(39.8 \%)$ & \\
\hline pT2 \& pT3 & 40 & $34(85.0 \%)$ & $6(15.0 \%)$ & \\
\hline
\end{tabular}

*Renal vein tumor thrombus included.

hypermethylation in $61.4 \%(54 / 88)$ of prostate cancers and $0 \%$ $(0 / 23)$ of benign prostatic hyperplasias. Hypermethylation of SSBP2 was associated with higher stage, and in a colony formation assay, SSBP2 expression inhibited tumour cell proliferation and induced cell cycle arrest (15). Huang et al. (16) reported that promoter methylation and down-regulation of SSBP2 were frequently detected in squamous cell carcinomas of the oesophagus and suggested that SSBP2 functions as a tumour suppressor that acts by inhibiting the Wnt signalling pathway. Brait et al. (17) detected promoter methylation at 13 genes, including SSBP2, in ovarian cancer. Although hypermethylation of SSBP2 was observed in 9\% (3 of 33 cases) of ovarian cancers, it was not statistically significant. Tsukamoto et al. (18) found that methylation of the $S S B P 2$ promoter was more frequently in gallbladder cancer than in cholecystitis. In addition, the oncogenic role of SSBP2 as a tumour promoter has also been suggested in glioblastoma. Using genotyping, Xiao et al. (19) identified a singlenucleotide polymorphism (Rs7732320), located in the intronic region of $S S B P 2$, with prognostic significance. They investigated whether patient outcome was correlated with the transcript levels of SSBP2 in 619 glioblastoma patients (from
3 publicly available gene expression data sets) (22-24). There was a strong and significant association between SSBP 2 gene expression and poor overall survival in glioblastoma patients (19). In this study, we observed low SSBP2 expression in $65.9 \%$ of ccRCC tissues and showed that SSBP2 loss was significantly associated with aggressive phenotypes, including larger tumour size, higher WHO/ISUP histologic grade, tumour necrosis, sarcomatoid change, higher pT AJCC stage, and worse recurrence-free survival.

To date, there have been no studies on SSBP2 expression in RCC. Dormoy et al. reported that the developmental marker Lim1 functions as an oncogene in ccRCC cells and suggested targeting Lim1 as an innovative therapeutic intervention for human ccRCC (20). SSBP2 and Lim1 are two of the various factors involved in regulating the transcriptional activity of LIM-homeodomain proteins, and their interactions are important in development $(11,25)$. Further molecular investigations are needed to provide a plausible mechanism for their function in oncogenesis.

As for the strength of this study, this is the only study identifying the significance of SSBP2 according to protein expression levels in ccRCC. Furthermore, we correlated 

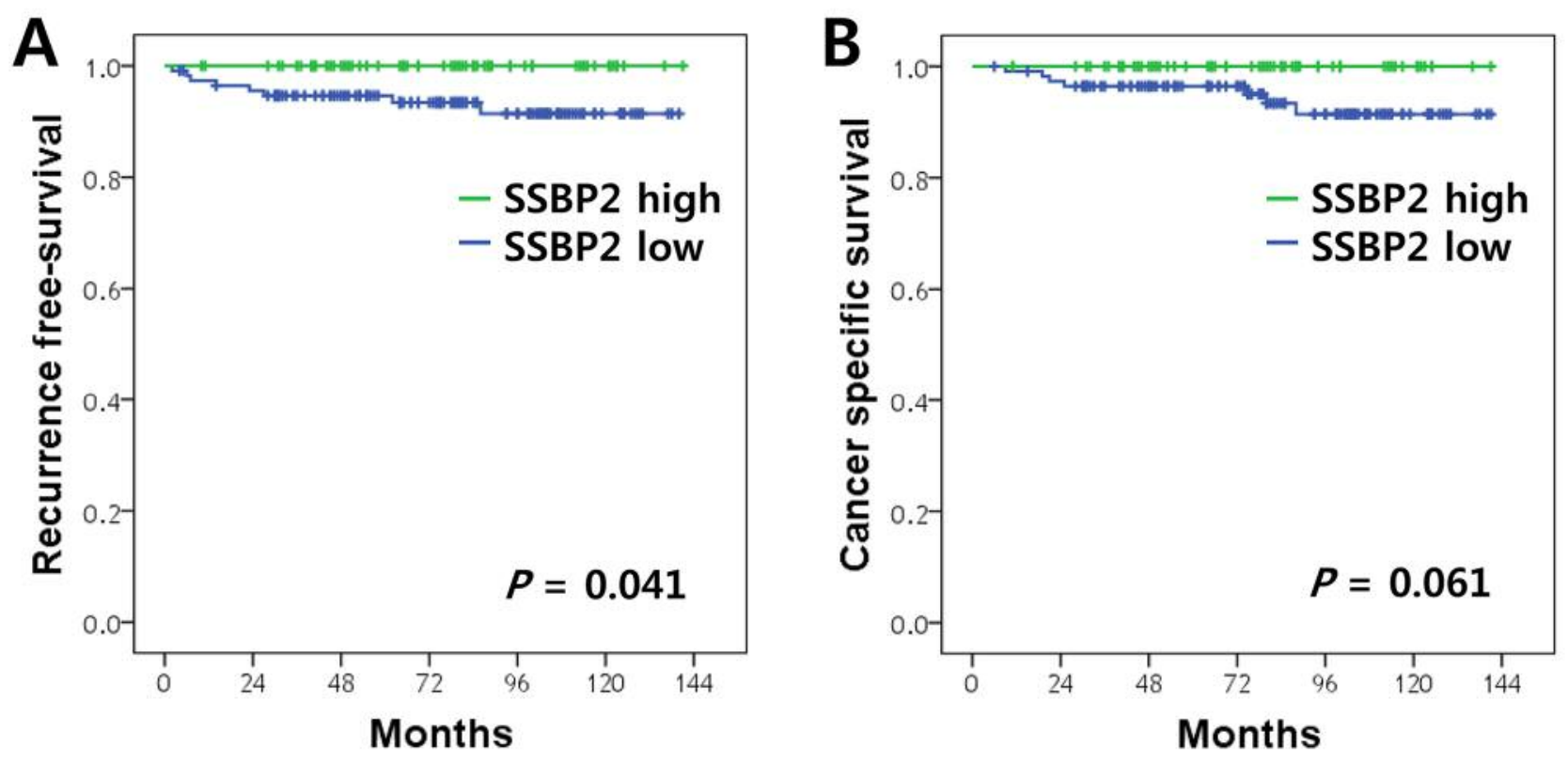

Figure 2. Kaplan-Meier survival curves of patients with clear cell renal cell carcinoma stratified by SSBP2 expression. (A) Recurrence-free survival $(p=0.041, \log$-rank test $)$ and $(B)$ cancer-specific survival $(p=0.061, \log$-rank test $)$.

various clinical and pathological parameters which practically related to prognosis with SSBP2 expression. However, there are several limitations. Firstly, this study was retrospective and was performed in a single medical centre with a limited number of patients. Secondly, other clinical factors, including Eastern Cooperative Oncology Group (ECOG) performance status, which may affect prognosis, were not considered, and SSBP2 was not statistically significant in multivariate analyses with well-known pathological prognostic factors (26). Thirdly, the detailed molecular mechanism underlying the role of SSBP2 expression in ccRCC was not studied. According to TCGA data (http://www.cbioportal.org), $0.4 \%$ (0.2\%, amplification; $0.2 \%$, missense mutation) of ccRCCs showed genetic alterations in $S S B P 2$.

In conclusion, a loss of SSBP2 expression was significantly correlated with aggressive phenotypes and poor recurrence-free survival in ccRCC. Further molecular investigations are needed to clarify the specific pathological mechanism of SSBP2 in ccRCC.

\section{Funding}

This research was supported by the Basic Science Research Program of the National Research Foundation of Korea (NRF) funded by the Ministry of Science, ICT, \& Future Planning (NRF2015R1C1A1A01056091) and the Ministry of Education (NRF2018R1D1A1B07048798).

\section{Conflicts of Interest}

The Authors declare that there are no conflicts of interest with regard to the present study.

\section{Authors' Contributions}

KJ built the conception and designed the experiments. YK, SB, SP, $\mathrm{SJ}$ and JS contributed to acquisition of clinicopathological data and construction of tissue microarray. HK performed the experiments. HK and KJ interpreted the results. SS and SSP assisted with interpretation of data. HK drafted manuscript. KJ, SS and SSP supervised the study. All authors read and approved the final manuscript.

\section{Acknowledgements}

The Authors would like to thank Jisook Kim and Jeong Yun Eom (Department of Pathology, Hanyang University Hospital) for excellent technical assistance.

\section{References}

1 Jung KW, Won YJ, Kong HJ and Lee ES: Prediction of cancer incidence and mortality in korea, 2018. Cancer Res Treat 50(2): 317-323, 2018. PMID: 29566480. DOI: 10.4143/crt.2018.142

2 Ljungberg B, Bensalah K, Canfield S, Dabestani S, Hofmann F, Hora M, Kuczyk MA, Lam T, Marconi L, Merseburger AS, Mulders P, Powles T, Staehler M, Volpe A and Bex A: Eau guidelines on renal cell carcinoma: 2014 update. Eur Urol 67(5): 
913-924, 2015. PMID: 25616710. DOI: 10.1016/j.eururo 2015.01.005

3 Dabestani S, Beisland C, Stewart GD, Bensalah K, Gudmundsson E, Lam TB, Gietzmann W, Zakikhani P, Marconi L, FernandezPello S, Monagas S, Williams SP, Torbrand C, Powles T, Van Werkhoven E, Meijer R, Volpe A, Staehler M, Ljungberg B and Bex A: Long-term outcomes of follow-up for initially localised clear cell renal cell carcinoma: Recur database analysis. Eur Urol Focus, 2018. PMID: 29525381. DOI: 10.1016/j.euf.2018.02.010

4 Nesiu A, Cimpean AM, Ceausu RA, Adile A, Ioiart I, Porta C, Mazzanti M, Camerota TC and Raica M: Intracellular chloride ion channel protein-1 expression in clear cell renal cell carcinoma. Cancer Genomics Proteomics 16(4): 299-307, 2019. PMID: 31243111. DOI: $10.21873 /$ cgp.20135

5 Zhao Z, Wu F, Ding S, Sun L, Liu Z, Ding K and Lu J: Labelfree quantitative proteomic analysis reveals potential biomarkers and pathways in renal cell carcinoma. Tumour Biol 36(2): 939951, 2015. PMID: 25315187. DOI: 10.1007/s13277-014-2694-2

6 Kovacova J, Juracek J, Poprach A, Kopecky J, Fiala O, Svoboda M, Fabian P, Radova L, Brabec P, Buchler T and Slaby O: Mir$376 b-3 p$ is associated with long-term response to sunitinib in metastatic renal cell carcinoma patients. Cancer Genomics Proteomics 16(5): 353-359, 2019. PMID: 31467229. DOI: $10.21873 / \operatorname{cgp} .20140$

7 Laba P, Wang $\mathrm{J}$ and Zhang $\mathrm{J}$ : Low level of isocitrate dehydrogenase 1 predicts unfavorable postoperative outcomes in patients with clear cell renal cell carcinoma. BMC Cancer 18(1): 852, 2018. PMID: 30153799. DOI: 10.1186/s12885-018-4747-1

8 Palumbo C, Furlan M, Balzarini P, Zanotelli T, Cozzoli A, Veccia A, Francavilla S, Zamboni S, Tardanico R, Simeone C and Antonelli A: Long-term prognostic impact of chromosome abnormalities in clear cell renal cell carcinoma. Anticancer Res 39(6): 2757-2765, 2019. PMID: 31177111. DOI: 10.21873/ anticanres.13402

9 Wang Y, Klumpp S, Amin HM, Liang H, Li J, Estrov Z, Zweidler-McKay P, Brandt SJ, Agulnick A and Nagarajan L: Ssbp2 is an in vivo tumor suppressor and regulator of $1 \mathrm{db} 1$ stability. Oncogene 29(21): 3044-3053, 2010. PMID: 20348955. DOI: $10.1038 /$ onc.2010.78

10 Li J, Kurasawa Y, Wang Y, Clise-Dwyer K, Klumpp SA, Liang H, Tailor RC, Raymond AC, Estrov Z, Brandt SJ, Davis RE, Zweidler-McKay P, Amin HM and Nagarajan L: Requirement for ssbp2 in hematopoietic stem cell maintenance and stress response. J Immunol 193(9): 4654-4662, 2014. PMID: 25238756. DOI: $10.4049 /$ jimmunol.1300337

11 Nishioka N, Nagano S, Nakayama R, Kiyonari H, Ijiri T, Taniguchi K, Shawlot W, Hayashizaki Y, Westphal H, Behringer RR, Matsuda Y, Sakoda S, Kondoh H and Sasaki H: Ssdp1 regulates head morphogenesis of mouse embryos by activating the lim1-ldb1 complex. Development 132(11): 2535-2546, 2005. PMID: 15857913. DOI: $10.1242 / \mathrm{dev} .01844$

12 Deane JE, Mackay JP, Kwan AH, Sum EY, Visvader JE and Matthews JM: Structural basis for the recognition of ldb1 by the n-terminal lim domains of $1 \mathrm{mo} 2$ and lmo4. Embo j 22(9): 22242233, 2003. PMID: 12727888. DOI: 10.1093/emboj/cdg 196

13 Matthews JM, Lester K, Joseph S and Curtis DJ: Lim-domainonly proteins in cancer. Nat Rev Cancer 13(2): 111-122, 2013. PMID: 23303138. DOI: $10.1038 / \mathrm{nrc} 3418$

14 Liang H, Samanta S and Nagarajan L: Ssbp2, a candidate tumor suppressor gene, induces growth arrest and differentiation of myeloid leukemia cells. Oncogene 24(16): 2625-2634, 2005. PMID: 15782145. DOI: 10.1038/sj.onc.1208167

15 Liu JW, Nagpal JK, Sun W, Lee J, Kim MS, Ostrow KL, Zhou $\mathrm{S}$, Jeronimo C, Henrique R, Van Criekinge W, Moon CS, Califano JA, Trink B and Sidransky D: Ssdna-binding protein 2 is frequently hypermethylated and suppresses cell growth in human prostate cancer. Clin Cancer Res 14(12): 3754-3760, 2008. PMID: 18559593. DOI: $10.1158 / 1078-0432$.ccr-07-4763

16 Huang Y, Chang X, Lee J, Cho YG, Zhong X, Park IS, Liu JW, Califano JA, Ratovitski EA, Sidransky D and Kim MS: Cigarette smoke induces promoter methylation of single-stranded DNAbinding protein 2 in human esophageal squamous cell carcinoma. Int J Cancer 128(10): 2261-2273, 2011. PMID: 20658532. DOI: $10.1002 /$ ijc. 25569

17 Brait M, Maldonado L, Noordhuis MG, Begum S, Loyo M, Poeta ML, Barbosa A, Fazio VM, Angioli R, Rabitti C, Marchionni L, de Graeff P, van der Zee AG, Wisman GB, Sidransky D and Hoque MO: Association of promoter methylation of vgf and pgp9.5 with ovarian cancer progression. PLoS One 8(9): e70878, 2013. PMID: 24086249. DOI: 10.1371/journal.pone. 0070878

18 Kagohara LT, Schussel JL, Subbannayya T, Sahasrabuddhe N, Lebron C, Brait M, Maldonado L, Valle BL, Pirini F, Jahuira M, Lopez J, Letelier P, Brebi-Mieville P, Ili C, Pandey A, Chatterjee A, Sidransky D and Guerrero-Preston R: Global and genespecific DNA methylation pattern discriminates cholecystitis from gallbladder cancer patients in chile. Future Oncol 11(2): 233-249, 2015. PMID: 25066711. DOI: 10.2217/fon.14.165

19 Xiao Y, Decker PA, Rice T, McCoy LS, Smirnov I, Patoka JS, Hansen HM, Wiemels JL, Tihan T, Prados MD, Chang SM, Berger MS, Kosel ML, Fridley BL, Lachance DH, O'Neill BP, Buckner JC, Thompson RC, Nabors LB, Olson JJ, Brem S, Madden MH, Browning JE, Wiencke JK, Egan KM, Jenkins RB and Wrensch MR: Ssbp2 variants are associated with survival in glioblastoma patients. Clin Cancer Res 18(11): 3154-3162, 2012. PMID: 22472174. DOI: 10.1158/1078-0432.ccr-11-2778

20 Dormoy V, Beraud C, Lindner V, Thomas L, Coquard C, Barthelmebs M, Jacqmin D, Lang H and Massfelder T: Limclass homeobox gene lim1, a novel oncogene in human renal cell carcinoma. Oncogene 30(15): 1753-1763, 2011. PMID: 21132009. DOI: 10.1038 /onc. 2010.557

21 English PA, Williams JA, Martini JF, Motzer RJ, Valota O and Buller RE: A case for the use of receiver operating characteristic analysis of potential clinical efficacy biomarkers in advanced renal cell carcinoma. Future Oncol 12(2): 175-182, 2016. PMID: 26674983. DOI: $10.2217 /$ fon. 15.290

22 Lee Y, Scheck AC, Cloughesy TF, Lai A, Dong J, Farooqi HK, Liau LM, Horvath S, Mischel PS and Nelson SF: Gene expression analysis of glioblastomas identifies the major molecular basis for the prognostic benefit of younger age. BMC Med Genomics 1: 52, 2008. PMID: 18940004 . DOI: $10.1186 / 1755-8794-1-52$

23 Murat A, Migliavacca E, Gorlia T, Lambiv WL, Shay T, Hamou MF, de Tribolet N, Regli L, Wick W, Kouwenhoven MC, Hainfellner JA, Heppner FL, Dietrich PY, Zimmer Y, Cairncross JG, Janzer RC, Domany E, Delorenzi M, Stupp R and Hegi ME: Stem cell-related "self-renewal" signature and high epidermal growth factor receptor expression associated with resistance to concomitant chemoradiotherapy in glioblastoma. J Clin Oncol 26(18): 3015-3024, 2008. PMID: 18565887. DOI: 10.1200/ jco.2007.15.7164 
24 Verhaak RG, Hoadley KA, Purdom E, Wang V, Qi Y, Wilkerson MD, Miller CR, Ding L, Golub T, Mesirov JP, Alexe G, Lawrence M, O'Kelly M, Tamayo P, Weir BA, Gabriel S, Winckler W, Gupta S, Jakkula L, Feiler HS, Hodgson JG, James CD, Sarkaria JN, Brennan C, Kahn A, Spellman PT, Wilson RK, Speed TP, Gray JW, Meyerson M, Getz G, Perou CM and Hayes DN: Integrated genomic analysis identifies clinically relevant subtypes of glioblastoma characterized by abnormalities in pdgfra, idh1, egfr, and nf1. Cancer Cell 17(1): 98-110, 2010. PMID: 20129251. DOI: 10.1016/j.ccr.2009.12.020

$25 \mathrm{Xu}$ Z, Meng X, Cai Y, Liang H, Nagarajan L and Brandt SJ: Single-stranded DNA-binding proteins regulate the abundance of lim domain and lim domain-binding proteins. Genes Dev 21(8): 942-955, 2007. PMID: 17437998. DOI: $10.1101 / \mathrm{gad}$ 1528507
26 Patard JJ, Kim HL, Lam JS, Dorey FJ, Pantuck AJ, Zisman A, Ficarra V, Han KR, Cindolo L, De La Taille A, Tostain J, Artibani W, Dinney CP, Wood CG, Swanson DA, Abbou CC, Lobel B, Mulders PF, Chopin DK, Figlin RA and Belldegrun AS: Use of the university of california los angeles integrated staging system to predict survival in renal cell carcinoma: An international multicenter study. J Clin Oncol 22(16): 3316-3322, 2004. PMID: 15310775. DOI: 10.1200/jco.2004.09.104

Received October 16, 2019

Revised October 31, 2019

Accepted November 5, 2019 